\title{
PERSEPSI KARYAWAN TENTANG PERAN AUDITOR INTERNAL SEBAGAI PENGAWAS, KONSULTAN DAN KATALISATOR DALAM PENCAPAIAN TUJUAN PERUSAHAAN
}

(Studi Kasus di Hotel Inna Garuda Yogyakarta)

Oleh:

Denies Priantinah

Megasari Chitra Adhisty

Denies_priantinah@yahoo.com

Mega_08412141035@yahoo.com

Fakultas Ekonomi Universitas Negeri Yogyakarta

\begin{abstract}
ABSTRAK
Penelitian ini merupakan penelitian deskriptif kuantitatif yang dilakukan di Hotel Inna Garuda Yogyakarta. Penelitian ini bertujuan untuk mengetahui bagaimana peran auditor internal Hotel Inna Garuda Yogyakarta sebagai pengawas, konsultan dan katalisator dalam pencapaian tujuan menurut persepsi karyawan.

Teknik pengambilan sampel yang digunakan dalam penelitian ini adalah Purposive Sampling, yang di mana pengambilan sampel dengan kriteria tertentu. kriteria tersebut diantaranya: karyawan berstatus karyawan tetap, masa kerja $\geq 2$ tahun, dan mengetahui tentang keberadaan auditor internal. Karyawan Hotel Inna Garuda Yogyakarta yang memenuhi kriteria tersebut dan dapat dijadikan responden dalam sampel sebanyak 69 karyawan. Metode pengumpulan data yang digunakan adalah wawancara dan kuesioner. Uji coba kuesioner dilakukan pada 30 karyawan yang memiliki kriteria sama dengan yang telah ditetapkan dan merupakan responden yang diambil di luar dari sampel. Uji coba kuesioner menggunakan uji validitas dengan menggunakan metode korelasi product moment pearson dan uji reliabilitas dengan menggunakan metode Cronbach's Alpha. Analisis data menggunakan analisis statistik deskriptif.

Berdasarkan hasil penelitian diketahui bahwa (1) persepsi karyawan tentang peran auditor internal sebagai pengawas dalam pencapaian tujuan perusahaan memiliki hasil perhitungan distribusi kecenderungan frekuensi dengan kategori cukup baik dan berdasarkan analisis data peran sebagai

pengawas menduduki peringkat I yaitu dengan total skor $1.625(37,17 \%)$. Peran yang dijalankan auditor internal perusahaan masing menganut paradigma lama yang sebenarnya saran dan rekomendasi yang diberikan peran ini hanya bersifat jangka pendek dalam membantu perusahaan untuk mencapai tujuan. (2) persepsi karyawan tentang peran auditor internal sebagai konsultan dalam pencapaian tujuan perusahaan memiliki hasil perhitungan distribusi kecenderungan frekuensi dengan kategori cukup baik dan berdasarkan analisis data peran sebagai konsultan menduduki peringkat II yaitu dengan total skor 1.395 (31,91\%). Auditor internal sebagai konsultan merupakan pihak pemberi saran dan rekomendasi yang membantu karyawan dalam memecahkan masalah terkait dengan kegiatan operasional perusahaan, akan tetapi peran sebagai konsultan yang dijalankan auditor internal kurang begitu dominan. (3) persepsi karyawan tentang peran auditor internal sebagai katalisator dalam pencapaian tujuan perusahaan memiliki hasil perhitungan distribusi kecenderungan frekuensi dengan kategori cukup baik dan berdasarkan analisis data peran sebagai katalisator menduduki peringkat III yaitu dengan total skor $1.352(30,92 \%)$. Peran auditor internal sebagai katalisator merupakan peran yang nantinya auditor internal akan ikut andil dalam penentuan tujuan perusahaan dan berdasarkan hasil penelitian peran ini menduduki peringkat akhir karena untuk menerapkan peran ini secara penuh membutuhkan waktu dan proses yang cukup panjang.

Kata Kunci: Peran Auditor Internal
\end{abstract}




\section{A. Pendahuluan}

\section{Latar Belakang}

Pada era globalisasi seperti sekarang ini, dengan berkembangnya praktik bisnis dan kebutuhan konsumen yang semakin kompleks, menyebabkan semakin ketatnya persaingan di dunia bisnis. Dunia bisnis selalu dihadapkan dengan konsep baru, sistem baru, dan prosedur baru. Terlebih lagi praktik bisnis yang bergerak di bidang yang sama akan mempertajam persaingan yang terjadi. Apabila perusahaan tidak mampu bersaing kemungkinan terburuk yang akan terjadi adalah kebangkrutan. Agar dapat bertahan dan tetap unggul, perusahaan berusaha menerapkan berbagai kebijakan dan strategi seperti peningkatan produktivitas, efisiensi, efektivitas dan pengendalian internal yang baik, tentunya diharapkan dapat memenuhi kebutuhan konsumen dan memberikan pelayanan yang terbaik.

Semakin berkembangnya perusahaan, tentunya semakin banyak departemen, bagian-bagian, atau unit -unit untuk menjalankan masing-masing fungsi sesuai prosedur. Melihat kondisi seperti ini manajemen perusahaan dihadapkan pada keterbatasan kemampuan untuk mengawasi dan mengendalikan operasi perusahaan sehingga manajemen mengandalkan peran auditor internal dalam mengatasi keterbatasan tersebut. (Suroso, 2009: 1)

Audit internal merupakan suatu aktivitas konsultasi yang dikelola secara independen dan objektif, yang dirancang sebagai penambah nilai untuk meningkatkan kegiatan operasional perusahaan. Secara efektif, auditor internal menyediakan informasi yang dibutuhkan manajer dalam melaksanakan tanggung jawab. Penilaian secara independen dilakukan auditor internal pada suatu perusahaan untuk menilai kegiatan operasional dengan mengukur dan mengevaluasi kecukupan kontrol serta efektivitas dan efisiensi dari kinerja perusahaan. (Sawyer, 2005: 7)

Awalnya auditor internal lebih berperan sebagai pengawas atau mata dan telinga manajemen karena manajemen membutuhkan kepastian terkait dengan pelaksanaan kebijakan yang telah ditetapkan untuk menghindari tindakan yang menyimpang. Di sini audit internal lebih berorientasi pada pelaksanaan tindakan pemeriksaan terhadap tingkat kepatuhan para pihak pelaksana dengan ketentuan-ketentuan yang ada dan ini sering dianggap sebagai tindakan yang konfrontatif. (Tampubolon, 2005: 1)

Seiring dengan berjalannya waktu, fokus utama audit internal mengalami pergeseran menjadi kon- sultan untuk perusahaan atau kliennya, yaitu membantu satuan kerja operasional mengelola risiko dengan mengidentifikasi masalah-masalah dan memberikan saran untuk tindakan perbaikan yang dapat memberikan tambahan nilai sebagai amunisi memperkuat organisasi. Bahkan untuk masa yang akan datang diprediksikan peran auditor internal akan menjadi katalisator yang di mana akan ikut serta dalam penentuan tujuan dari suatu perusahaan atau organisasi. (Tampubolon, 2005:2)

Penelitian yang dilakukan oleh Listiatik (2007) menyebutkan bahwa peran auditor internal menimbulkan perbedaan persepsi karyawan Rumah Sakit Panti Rini. Ada beberapa karyawan memiliki persepsi bahwa auditor internal sebagai kawan karena menganggap dengan keberadaan auditor internal sebagai konsultan dan katalisator yang dapat memberikan kontribusi berupa saran atau masukan dalam pencapaian tujuan perusahaan. Di sisi lain, ada sebagian karyawan yang memiliki persepsi bahwa auditor internal adalah lawan karena melihat peran sebagai pengawas yang dijalankan auditor internal seperti layaknya polisi yang melakukan pemeriksaan. Tentunya persepsi tentang peran auditor internal sebagai lawan dan sebagai kawan akan memberikan dampak pada kegiatan operasional Rumah Sakit Panti Rini.

Di samping itu, keberadaan auditor internal yang memberikan banyak manfaat bagi perusahaan membuat banyak manajemen perusahaanperusahaan besar membentuk tim audit internal. Salah satunya yang memanfaatkan auditor internal dalam perusahaan adalah hotel berbintang milik Badan Usaha Milik Negara (BUMN) di Yogyakarta yaitu Hotel Inna Garuda. Auditor internal di Hotel Inna Garuda Yogyakarta dikenal dengan sebutan Satuan Pengawas Internal (SPI). Dengan adanya SPI sebagai auditor internal diharapkan dapat mempermudah perusahaan untuk melakukan pengawasan dan pengendalian atas kegiatankegiatan yang berjalan di Hotel Inna Garuda Yogyakarta sehingga tujuan yang hendak dicapai perusahaan dapat terealisasikan.

Auditor internal Hotel Inna Garuda Yogyakarta merupakan pihak yang dipercaya oleh perusahaan untuk melakukan evaluasi pada pelaksanaan kegiatan yang dilakukan sebagai tindakan atau upaya dalam membantu pencapaian tujuan perusahaan. Pelaksanaan verifikasi terhadap dokumendokumen transaksi untuk mendapatkan kesesuaian transaksi dan catatan serta auditor internal menilai secara independen aktivitas atau kegiatan karyawan, apakah pelayanan yang diberikan dapat me- 
menuhi kebutuhan konsumen. Kegiatan audit internal dilakukan untuk memperbaiki kinerja dan membantu perusahaan dalam mencapai atau merealisasikan tujuan yang tercermin dalam visi dan misi perusahaan.

Pernyataan tentang tujuan perusahaan tercermin dalam visi didukung dengan definisi yang diungkapkan oleh Kotler yang mengemukakan bahwa visi adalah pernyataan tentang tujuan organisasi yang diekspresikan dalam produk dan pelayanan yang tawarkan, kebutuhan yang dapat diatasi, nilai-nilai yang diperoleh serta aspirasi dan cita -cita masa depan. Sedangkan pernyataan tentang tujuan perusahaan tercermin dalam misi juga didukung dengan definisi yang diungkapkan oleh Wheelen yang mengemukakan bahwa misi merupakan rangkaian kalimat yang menyatakan tujuan atau alasan eksistensi perusahaan yang memuat apa yang disediakan oleh perusahaan pada masyarakat atau konsumen, baik jasa ataupun produk. (Wibisono: 2006, 46)

Kegiatan evaluasi, verifikasi dan penilaian yang dilakukan auditor internal serta saran dan rekomendasi yang diberikan selama ini dianggap oleh beberapa karyawan kurang memberikan kontribusi yang maksimal dalam membantu pencapaian tujuan perusahaan. Bahkan terkadang kegiatan auditor internal yang melakukan penilaian pada kinerja karyawan membuat karyawan merasa tidak nyaman karena setiap tindakan yang mereka lakukan akan diawasi. Dengan hal tersebut memungkinkan timbulnya perasaan tidak percaya karyawan terhadap peran yang dijalankan oleh auditor internal. Pada kenyataannya dalam membantu pencapaian tujuan perusahaan, Hotel Inna Garuda Yogyakarta memerlukan auditor internal yang tidak hanya berfokus pada penemuan kecurangan yang terjadi tetapi berperan juga sebagai konsultan internal yang memberikan masukan dan pemikiran serta adanya audit internal dalam menunjang efektivitas pengendalian atas kegiatan-kegiatan yang berjalan di Hotel Inna Garuda Yogyakarta.

Penelitian ini dilakukan untuk mengetahui bagaimana para karyawan melihat jabatan auditor internal Hotel Inna Garuda Yogyakarta dan apa peran dari pekerjaan auditor internal dalam membantu pencapaian tujuan perusahaan selama ini, oleh karena itu berdasarkan uraian di atas, peneliti tertarik untuk melakukan penelitian tentang "Persepsi Karyawan Tentang Peran Auditor Internal Sebagai Pengawas, Konsultan Dan Katalisator Dalam Pencapaian Tujuan Perusahaan (Studi Kasus Di Hotel Inna Garuda Yogyakar- ta)". Peneliti memilih lokasi obyek penelitian Hotel Inna Garuda Yogyakarta karena di Hotel Inna Garuda Yogyakarta terdapat permasalahan yang cukup menarik untuk dilakukan penelitian, informasi dan data dapat diperoleh dengan mudah, serta Hotel Inna Garuda Yogyakarta merupakan hotel yang cukup representatif untuk dilakukannya penelitian.

\section{Rumusan Masalah}

Berdasarkan pembatasan masalah di atas, permasalahan yang diteliti dapat dirumuskan sebagai berikut: Bagaimana peran auditor internal sebagai pengawas, konsultan, dan katalisator dalam pencapaian tujuan perusahaan menurut persepsi karyawan?

\section{Tujuan Penelitian}

Tujuan penelitian yang ingin dicapai adalah untuk mengetahui bagaimana peran auditor internal sebagai pengawas, konsultan, dan katalisator dalam pencapaian tujuan perusahaan menurut persepsi karyawan.

\section{Kajian Teori \\ a. Auditor Internal}

Pada bulan Juli 1999 Dewan Direksi The Institute of internal Auditors (IIA) mengadopsi definisi audit internal sebagai berikut:

Audit Internal adalah aktivitas independen, keyakinan objektif dan konsultasi yang dirancang untuk memberikan nilai tambah dan meningkatkan operasi organisasi. Audit tersebut membantu organisasi mencapai tujuannya dengan menerapkan pendekatan secara sistematis dan berdisiplin untuk mengevaluasi dan meningkatkan efektivitas proses pengelolaan resiko, kecukupan kontrol dan pengelolaan organisasi. Sedangkan dalam Sukrisno Agoes (2004: 221) definisi internal audit sebagai berikut: Audit Internal adalah pemeriksaan yang dilakukan oleh bagian internal audit perusahaan, baik terhadap laporan keuangan dan catatan akuntansi perusahaan, maupun ketaan terhadap kebijakan manajemen puncak yang telah ditentukan dan ketaatan terhadap peraturan pemerintah dan ketentuanketentuan dari ikatan profesi yang berlaku. Peraturan pemerintah seperti peraturan di bidang perpajakan, pasar modal, lingkungan hidup, perbankan, perindustiran, investasi dan lain-lain. Ketentuanketentuan dari ikatan profesi misalnya standar akuntansi keuangan.

Dari uraian definisi-definisi di atas peneliti dapat 
menarik kesimpulan bahwa audit internal adalah aktivitas pemeriksaan dan pemberian jasa konsultasi yang dikelola secara independen dan efektif sehingga dapat membantu memberikan nilai tambah untuk aktivitas operasional perusahaan dan membatu dalam pencapaian tujuan perusahaan yang telah ditetapkan.

\section{b. Peran Auditor Internal dalam Pencapaian Tujuan Perusahaan}

Dewasa ini peran auditor internal dirasakan semakin penting oleh organisasi perusahaan. Menjadi sangat penting bagi suatu perusahaan untuk mempunyai tim spesialis yang menelaah prosedur- prosedur dan operasi dari berbagai unit dan melaporkan ketidaktaatan suatu tindakan, inefisiensi, dan tidak adanya kendali jelas bahwa tugas itu tidak dapat dibebani pada auditor eksternal yang tujuan utamanya adalah menilai apakah laporan keuangan mencerminkan secara wajar hasil-hasil usaha serta kondisi keuangan usaha suatu perusahaan. Karena itu audit internal telah menjadi suatu pemberian jasa yang tidak hanya memiliki keahlian akuntansi tetapi juga keahlian dalam perilaku organisasi atau perusahaan dan bidang-bidang fungsional lainnya.

Peran Auditor Internal menurut Tampubolon (2005: 1-2) sebagai berikut:

Tabel 1. Peran Auditor Internal

\begin{tabular}{|l|l|l|}
\hline \multirow{2}{*}{ Uraian } & \multicolumn{2}{|c|}{ Peran Auditor Internal } \\
\cline { 2 - 3 } & \multicolumn{1}{|c|}{ Paradigma Lama } & \multicolumn{1}{c|}{ Paradigma Baru } \\
\hline Peran & Pengawas & Konsultan dan Katalisator \\
\hline Pendekatan & $\begin{array}{l}\text { Detektif (mendeteksi ter- } \\
\text { jadinya suatu masalah) }\end{array}$ & $\begin{array}{l}\text { Prefentif (mencegah masa- } \\
\text { lah) }\end{array}$ \\
\hline Sikap & $\begin{array}{l}\text { Seperti layaknya seorang } \\
\text { polisi }\end{array}$ & $\begin{array}{l}\text { Sebagai mitra bagi perus- } \\
\text { ahaan }\end{array}$ \\
\hline Ketaatan/ \\
kepatuhan & Semua policy/kebijakan & $\begin{array}{l}\text { Hanya policy yang relevan } \\
\text { Fokus }\end{array}$ \\
\hline Audit & $\begin{array}{l}\text { Kelemahan/ } \\
\text { penyimpangan }\end{array}$ & $\begin{array}{l}\text { Penyelesaian yang kon- } \\
\text { struktif }\end{array}$ \\
\hline $\begin{array}{l}\text { Dampak yang } \\
\text { diberikan }\end{array}$ & audit & $\begin{array}{l}\text { Financial, compliance, } \\
\text { operational audit, quality } \\
\text { assurance }\end{array}$ \\
\hline
\end{tabular}

Sumber: Tampubolon (2005:1-3)

1) Peran auditor internal sebagai pengawas

Pada awalnya audit internal dikenal sebagai suatu pendekatan berbasis pada sistem yang dalam perkembangan selanjutnya beralih ke internal audit berbasis proses. Pada saat itu auditor internal lebih banyak berperan sebagai mata dan telinga manajemen, karena manajemen butuh kepastian bahwa semua kebijakan yang ditetapkan akan dilaksanakan oleh pegawai. Orientasi auditor internal banyak dilakukan pemeriksaan pada tingkat kepatuhan para pelaksana terhadap ketentuanketentuan yang ada (compliance). (Tampubolon, 2005: 1-2)

Fokus dari audit ini adalah ditemukannya penyim- pangan yang perlu dikoreksi, keterlambatan, kesalahan, prosedur atau pengendalian internal dan segala hal yang dampaknya hanya bersifat jangka pendek. Aktivitasnya yaitu meliputi inspeksi, observasi, perhitungan, pengecekan yang memiliki tujuan dalam memastikan kepatuhan dan ketaatan pada ketentuan, kebijakan serta peraturan yang telah ditetapkan. Peran auditor internal sebagai pengawas biasanya menghasilkan saran atau rekomendasi yang memberikan dampak jangka pendek.

Dari uraian di atas dapat diketahui bahwa peran auditor internal sebagai pengawas sama halnya dengan tugas polisi. Telah kita ketahui polisi memiliki tugas untuk mengamankan dan menjaga ket- 
ertiban kehidupan masyarakat sehingga peneliti dapat menarik kesimpulan peran auditor internal sebagai pengawas dapat diartikan sama dengan polisi, yaitu auditor internal memiliki tugas untuk menjaga keamanan, kelancaran, kesesuaian aktivitas dengan peraturan yang berlaku di perusahaan tertentu, di mana dengan tindakannya itu membantu perusahaan dalam pencapaian tujuan jangka pendek.

\section{2) Peran auditor internal sebagai konsultan.}

Dunia usaha yang semakin berkembang dan mulai menyadari bahwa dalam menjalani suatu usaha mengandung risiko, mulailah bermunculan mengenai kebutuhan untuk mengimplementasikan internal audit berbasis risiko (Risk Based Internal Auditing). Sesuai dengan definisi baru, kegiatan audit internal bertujuan untuk memberikan layanan pada organisasi. Karena kegiatan tersebut, maka auditor internal memiliki fungsi sebagai pemeriksa sekaligus berfungsi sebagai mitra manajemen. Pada dasarnya seluruh tingkatan manajemen dapat menjadi klien auditor internal. Oleh karena itu auditor internal wajib melayani klien dengan baik dan mendukung kepentingan klien dengan tetap mempertahankan loyalitasnya. (Tampubolon, 2005: 1-2)

Peran konsultan yang dijalankan auditor internal diharapkan dapat membantu satuan kerja operasional dalam mengelola risiko dengan mengidentifikasi masalah dan memberikan saran untuk tindakan perbaikan yang memberi nilai tambah untuk memperkuat organisasi. Audit yang dilakukan yaitu audit operasional dengan memberikan keyakinan bahwa organisasi telah memanfaatkan sumber daya organisasi yang ada secara efektif, efisien dan ekonomis. Rekomendasi yang diberikan auditor internal biasanya bersifat jangka menengah. Peran sebagai konsultan mengharuskan dan membawa auditor internal untuk selalu meningkatkan pengetahuan yang dimilikinya baik terkait dengan profesi auditor maupun aspek bisnis, sehingga dapat membantu manajemen dalam mengantisipasi terjadinya masalah. (Supriyanto Ilyas dan Maulana, 2007: 5)

Pada tahun 1999 The Institute Internal Auditor melakukan redefinisi pada audit internal. Dijelaskan bahwa audit internal merupakan suatu aktivitas independen dalam dalam menetapkan tujuan dan merancang aktivitas konsultasi yang bernilai tambah dan meningkatkan operasi perusahaan. Dari redefinisi yang dilakukan The Institute Internal Auditor terlihat audit internal membantu suatu organisasi atau perusahaan dalam pencapaian tujuan dengan pendekatan yang terarah dan sistematis untuk menilai dan mengevaluasi keefektifan manajemen risiko melalui pengendalian dan proses tata kelola yang baik. Dari uraian di atas, peneliti dapat menarik kesimpulan bahwa peran auditor internal sebagai konsultan selain bertugas melakukan pengawasan, peran ini juga bertugas sebagai mitra dalam mengelola risiko dan memberikan masukan, rekomendasi, nasihat-nasihat yang diharapkan dapat membantu dalam pemecahan masalah yang sedang dihadapi karyawan, terutama masalah yang berhubungan dengan kegiatan operasional perusahaan sehingga tujuan perusahaan dapat tercapai.

\section{3) Peran auditor internal sebagai katalisator.}

Auditor internal di masa mendatang dimungkinkan berperan sebagai katalisator yang akan ikut andil dalam menentukan tujuan perusahaan. Perubahan penuh ke arah Risk Based Internal Auditing (RBIA) akan terjadi, yang di mana auditor internal akan ikut berperan mulai dari penentuan tujuan yang hendak dicapai sampai dengan mementukan tindakan-tindakan apa yang harus dilakukan untuk mencapai tujuan yang telah ditetapkan tersebut. Peran yang dijalankan auditor internal sebagai katalisator adalah mengarahkan agar pelaksanaan quality management dapat sesuai dengan yang direncanakan. Peran auditor internal sebagai katalisator bertindak sebagai fasilitator dan agent of change. (Harry Andrian Simbolon, 2010: 1)

Auditor internal sebagai katalisator terlibat aktif dalam melakukan penilaian risiko yang terdapat dalam proses bisnis perusahaan. Oleh karena itu diperlukan sikap proaktif dari pihak auditor internal dalam mengenali risiko-risiko yang dihadapi atau mungkin dihadapi manajemen dalam pencapaian tujuan perusahaan. Peran katalisator yang dijalankan auditor internal tidak saja terbatas pada tindakan perbaikan dan memberikan nasihat tetapi juga mencakup dalam system design and development, review terhadap kompetensi sumberdaya manusia dalam suatu fungsi organisasi, keterlibatan dalam penyusunan corporate planning, evaluasi kinerja, budgeting, strategy formulation dan usulan perubahan strategi (Harry Andrian Simbolon, 2010: 1). Peneliti menyimpulkan peran auditor internal sebagai katalisator hampir sama dengan peran auditor internal sebagai konsultan yang merupakan paradigma baru dari peran auditor internal. Peran ini mendampingi klien dalam mengenali resiko yang dapat mengancam pencapaian tujuan perusahaan dan akan ikut bertugas dan bekerjasama dengan manajemen dalam penentuan tujuan dari suatu perusahaan yang berdampak 
untuk jangka panjang.

\section{Persepsi}

Menurut Kreitner dan Kinicki (2003: 208) "Persepsi adalah proses kognitif yang memungkinkan kita dapat menafsirkan dan memahami lingkungan di sekitar kita". Penafsiran tersebut merupakan pandangan kita tentang lingkungan atau tempat di mana kita berada. Menurut Matlin dan Solso dalam Suharnan (2005: 23) "Persepsi adalah suatu proses penggunaan pengetahuan yang telah dimili$\mathrm{ki}$ (yang disimpan di dalam ingatan) untuk mendeteksi atau memperoleh dan menginterpretasi stimulus (rangsangan) yang diterima oleh alat indera seperti mata, telinga dan hidung". Menurut Walgito (2005: 102) terjadinya persepsi merupakan sesuatu yang terjadi dalam tahap-tahap berikut:

1. Tahap pertama, merupakan tahap yang dikenal dengan nama proses fisik, merupakan proses ditangkapnya suatu stimulus oleh alat indera manusia.

2. Tahap kedua, merupakan tahap yang dikenal dengan proses fisiologis yang merupakan proses diteruskannya stimulus yang diterima oleh alat indera atau reseptor melalui saraf-saraf sensoris.

3. Tahap ketiga, merupakan tahap yang dikenal dengan nama proses psikologis, merupakan proses timbulnya kesadaran individu tentang stimulus yang diterima alat indera atau reseptor.

4. Tahap keempat, merupakan hasil perolehan dari proses persepsi, berupa tanggapan dan perilaku.

\section{B. Metode Penelitian}

\section{Jenis Penelitian}

Jenis penelitian ini adalah penelitian deskriptif dengan unit analisis adalah karyawan tetap Hotel Inna Garuda Yogyakarta. Penelitian deskriptif (Descriptive Research) merupakan penelitian terhadap masalah-masalah berupa faktafakta saat ini dari suatu populasi (Nur Indriantoro dan Bambang Supomo, 1999:29). Tujuan penelitian deskriptif adalah untuk menjawab pertanyaan yang berkaitan dengan current status dari subjek yang diteliti.

\section{Populasi dan Sampel Penelitian}

Populasi adalah wilayah generalisasi yang terdiri atas objek atau subjek yang mempunyai kualitas dan karakteristik tertentu yang ditetapkan oleh peneliti untuk dipelajari dan kemudian ditarik kesimpulannya (Sugiyono, 2008: 115). Populasi yang akan digunakan dalam penelitian ini adalah karyawan yang bekerja di Hotel Inna Garuda Yogyakarta. Berdasarkan data yang diperoleh dari pihak Hotel Inna Garuda Yogyakarta, jumlah seluruh karyawan Hotel Inna Garuda Yogyakarta berjumlah 230 orang. Sampel adalah bagian dari jumlah dan karakteristik yang dimiliki populasi tersebut (Sugiyono, 2008: 116). Teknik yang digunakan untuk pengambilan sampel dalam penelitian ini adalah Purposive Sampling yaitu dengan menggunakan pertimbangan tertentu. Pertimbangan tertentu tersebut adalah responden yang diminta untuk mengisi kuesioner harus memenuhi beberapa kriteria yaitu diantaranya berstatus karyawan tetap, masa kerja $\geq 2$ tahun, dan mengetahui tentang keberadaan audit internal. Rumus yang digunakan untuk menghitung ukuran sampel dari populasi adalah rumus yang dikemukakan dalam buku Suharsimi Arikunto (2005: 95) disebutkan apabila peneliti memiliki beberapa ratus subjek dalam populasi maka dapat menentukan kurang lebih $25 \%$ sampai $30 \%$ dari jumlah subjek tersebut. Berdasarkan rumus dan jumlah karyawan yang memenuhi kriteria di atas maka jumlah sampel yang digunakan dalam penelitian ini adalah sebanyak $30 \% \times 230$ orang $=69$ orang.

\section{Teknik Pengumpulan Data}

\section{a. Wawancara}

Mengajukan pertanyaan-pertanyaan secara lisan kepada pihak-pihak yang berhubungan dan mengetahui keberadaan auditor internal Hotel Inna Garuda Yogyakarta untuk mendapatkan informasi tambahan mengenai kerja dan kegiatan dari auditor internal.

\section{b. Kuesioner}

Menyebarkan daftar pernyataan yang diajukan secara tertulis beserta pilihan yang telah tersedia.

Responden yang dalam hal ini adalah karyawan tetap Hotel Inna Garuda Yogyakarta diminta untuk memilih salah satu jawaban yang terdapat dalam kuesioner sesuai dengan apa yang dialami. Pengukuran pernyataan peneliti dalam kuesioner menggunakan Skala Likert. Skala Likert digunakan untuk mengukur sikap, pendapat, dan persepsi seseorang atau sekelompok orang mengenai fenomena sosial. (Sugiyono, 2008: 86). Pernyataan peneliti dan jawaban responden dikemukakan secara tertulis melalui kuesioner dengan Skala Likert yang dimodifikasi, seperti sebagai berikut: 


\section{Jurnal Nominal / Volume I Nomor I / Tahun 2012}

\begin{tabular}{|c|c|}
\hline Jawaban & Skor Penilaian \\
\hline Sangat setuju & 4 \\
\hline Setuju & 3 \\
\hline Tidak setuju & 2 \\
\hline Sangat tidak setuju & 1 \\
\hline
\end{tabular}

Tabel 2. Skor Penilaian Kuesioner

Sumber: Sugiyono (2008)

Untuk mengurangi kecenderungan responden menjawab ragu-ragu/netral, maka pada penelitian ini pilihan jawaban ragu-ragu/netral tidak disajikan sebagai alternatif jawaban bagi responden.

\section{Analisis Data}

a. Pengujian Instrumen Penelitian

\section{1) Uji Validitas}

Uji validitas dilakukan untuk mengukur akurasi suatu instrumen pengukuran. Instrumen tersebut dapat mengukur konstrak sesuai dengan yang diharapkan. (Nur Indriantoro dan Bambang Supomo, 1999: 181). Uji validitas yang digunakan dalam penelitian ini adalah dengan menggunakan metode korelasi product moment pearson dari Karl Pearson, dengan rumus:

$$
\mathrm{r}=\frac{n\left(\sum X Y\right)-\left(\sum X \sum Y\right)}{\sqrt{\left[n \sum X^{2}-\left(\sum X\right)^{2}\right]\left[n \sum Y^{2}-\left(N \sum Y^{2}\right]\right.}}
$$

Pelitian ini menggunakan metode korelasi product moment pearson dengan bantuan software SPSS dan hasilnya dibandingkan dengan $r$ tabel. Jika $r$ hitung $>r$ tabel maka pertanyaan valid. Skor tiap butir pernyataan per variabel dimasukkan disertai dengan jumlah skor tiap butir pernyataan.

Kuesioner yang disebarkan untuk uji validitas dalam penelitian ini sebanyak 30 kuesioner. Uji coba validitas instrumen yang dilakukan adalah menggunakan program IBM SPSS versi 19. Dilakukan dengan membandingkan nilai $r$ hitung dengan $r$ tabel untuk degree of freedom $(\mathrm{df})=\mathrm{n}-$ 2. Dalam penelitian ini $\mathrm{n}=30$ maka $(\mathrm{df})=28$, tingkat signifikansi 5\%, sehingga pada tabel diperoleh angka $r$ tabel $=0,361$. Berikut ringkasan hasil uji coba validitas instrumen:
Tabel 3. Ringkasan Hasil Uji Coba Validitas Instrumen Peran Auditor Internal sebagai Pengawas dalam Pencapaian Tujuan Perusahaan

Sumber: Dara primer yang diolah 2012

\begin{tabular}{|l|l|l|l|}
\hline Pernyataan & \multicolumn{1}{|c|}{$r$ hitung } & \multicolumn{1}{|c|}{$r$ tabel } & \multicolumn{1}{|c|}{ Keterangan } \\
\hline P1 & 0,734 & 0,361 & Valid \\
\hline P2 & 0,671 & 0,361 & Valid \\
\hline P3 & 0,591 & 0,361 & Valid \\
\hline P4 & 0,779 & 0,361 & Valid \\
\hline P5 & 0,512 & 0,361 & Valid \\
\hline P6 & 0,701 & 0,361 & Valid \\
\hline P7 & 0,697 & 0,361 & Valid \\
\hline P8 & 0,469 & 0,361 & Valid \\
\hline
\end{tabular}

Tabel 4. Ringkasan Hasil Uji Coba Validitas Instrumen Peran Auditor Internal sebagai Konsultan dalam Pencapaian Tujuan Perusahaan

Sumber: Dara primer yang diolah 2012

\begin{tabular}{|l|l|l|l|}
\hline Pernyataan & \multicolumn{1}{|c|}{$r$ hitung } & \multicolumn{1}{c|}{$r$ tabel } & \multicolumn{1}{|c|}{ Keterangan } \\
\hline K1 & 0,594 & 0,361 & Valid \\
\hline K2 & 0,704 & 0,361 & Valid \\
\hline K3 & 0,799 & 0,361 & Valid \\
\hline K4 & 0,704 & 0,361 & Valid \\
\hline K5 & 0,798 & 0,361 & Valid \\
\hline K6 & 0,678 & 0,361 & Valid \\
\hline K7 & 0,644 & 0,361 & Valid \\
\hline K8 & 0,551 & 0,361 & Valid \\
\hline
\end{tabular}

Tabel 5. Ringkasan Hasil Uji Coba Validitas Instrumen Peran Auditor Internal sebagai Katalisator dalam Pencapaian Tujuan Perusahaan

Sumber: Dara primer yang diolah 2012

\begin{tabular}{|l|l|l|l|}
\hline Pernyataan & \multicolumn{1}{|c|}{$r$ hitung } & \multicolumn{1}{c|}{$r$ tabel } & \multicolumn{1}{|c|}{ Keterangan } \\
\hline Kt1 & 0,627 & 0,361 & Valid \\
\hline Kt2 & 0,649 & 0,361 & Valid \\
\hline Kt3 & 0,685 & 0,361 & Valid \\
\hline Kt4 & 0,687 & 0,361 & Valid \\
\hline Kt5 & 0,517 & 0,361 & Valid \\
\hline Kt6 & 0,576 & 0,361 & Valid \\
\hline Kt7 & 0,586 & 0,361 & Valid \\
\hline Kt8 & 0,437 & 0,361 & Valid \\
\hline
\end{tabular}

2) Uji Reliabilitas

Uji reliabilitas diukur melalui pendekatan relia- 
bilitas konsistensi internal (internal consistency reliability). Dilakukan untuk melihat konsistensi diantara butir-butir pertanyaan atau pernyataan dalam suatu instrumen. Tingkat keterkaitan antar butir pertanyaan atau pernyataan dalam suatu instrumen untuk mengukur konstrak tertentu menunjukkan tingkat reliabilitas konsisten internal instrumen yang bersangkutan (Nur Indriantoro dan Bambang Supomo, 1999: 181. Dalam penelitian ini teknik yang digunakan untuk mengukur konsistensi internal yaitu Cronbach's alpha yang tolak ukur atau patokan yang digunakan untuk menafsirkan korelasi antara skala yang dibuat dengan semua skala variabel yang ada, dengan rumus sebagai berikut:

$$
\mathrm{r}_{\mathrm{n}}=\left[\frac{k}{k-1}\right]\left[1-\frac{\sum \sigma_{\mathrm{t}}^{2}}{\sigma_{\mathrm{t}}^{2}}\right]
$$

Pengujian dilakukan pada tiap butir pernyataan per variabel. Suatu konstrak atau variabel dikatakan reliabel jika memberikan nilai Cronbach's alpha $>$ 0,60 . Berikut ringkasan hasil uji coba reliabilitas instrumen dengan bantuan program IBM SPSS versi 19:

Tabel 6. Ringkasan Hasil Uji Coba Reliabilitas Instrumen

\begin{tabular}{|l|l|l|}
\hline \multicolumn{1}{|c|}{ Instrumen } & $\begin{array}{c}\text { Cronbach' }^{\prime} \\
\text { s alpha }\end{array}$ & $\begin{array}{c}\text { Kes- } \\
\text { impulan }\end{array}$ \\
\hline $\begin{array}{l}\text { peran auditor internal sebagai } \\
\text { pengawas dalam pencapaian } \\
\text { tujuan perusahaan }\end{array}$ & 0,805 & Reliabel \\
\hline $\begin{array}{l}\text { peran auditor internal sebagai } \\
\text { konsultan dalam pencapaian } \\
\text { tujuan perusahaan }\end{array}$ & 0,838 & Reliabel \\
\hline $\begin{array}{l}\text { peran auditor internal sebagai } \\
\text { katalisator dalam pencapaian } \\
\text { tujuan perusahaan }\end{array}$ & 0,742 & Reliabel \\
\hline
\end{tabular}

Sumber: Dara primer yang diolah 2012

\section{b. Analisis Statistik Deskriptif}

Teknik analisis data yang digunakan untuk jenis penelitian deskriptif ini adalah teknik analisis statistik desktiptif. Teknik analisis ini telah digunakan oleh peneliti terdahulu untuk penelitian mengenai persepsi, yaitu diantaranya oleh Emanuela Deasy Novieyanti (2006), yang berjudul "Persepsi Karyawan Terhadap Peran Audit Internal pada Pelayanan Kesehatan St. Carolus Jakarta" dan penelitian yang dilakukan oleh Anita Romauli M (2011), dengan judul penelitian "Persepsi Mahasiswa Akuntansi Tentang Standar Akuntansi Keuangan Entitas Tanpa Akuntabilitas Publik (SakEtap) Bagi Usaha Mikro Kecil Dan Menengah". Statistik deskriptif bisa didefinisikan sebagai proses pengumpulan, penyajian, dan meringkas berbagai karakteristik dari data dalam upaya untuk menggambarkan data tersebut secara memadai dan merupakan teknik yang digunakan untuk menjawab pertanyaan penelitian yang telah dirumuskan dari permasalahan yang terjadi. (Singgih, 2003: 32).

1) Pengumpulan dan Penyajian Data

Data dikumpulkan dan diorganisasikan dengan kriteria tertentu dan disajikan dalam bentuk tabel atau grafik. Data ditampilkan menggunakan tabel kontingensi dan tabel distribusi frekuensi. Tabel kontingensi digunakan jika data berbentuk kualitatif. Distribusi Frekuensi menyusun dan mengatur data kuantitatif yang masih mentah ke dalam beberapa kelas data yang sama, sehingga setiap kelas bisa menggambarkan karakeristik data yang sama. Proses pembuatan distribusi Frekuensi:

a) Menentukan Jumlah Kelas. H.A. Sturges mengajukan sebuah rumus menentukan jumlah kelas dari sekelompok data:

$$
\mathrm{K}=1+3,3 \log \mathrm{n}
$$

b) Menentukan Kelas Interval. Setelah jumlah kelas ditetapkan, selanjutnya mengisi interval tiap kelas dengan rumus:

$$
i=\frac{\text { range }}{k}
$$

c) Panjang Kelas: panjang kelas didapat dari range dibagi dengan jumlah kelas.

2) Karakteristik Data

Central Tendency, yaitu yang berupa Mean, Median, atau Modus.

Dipersion yang berupa range, varians dan standar deviasi.

\section{3) Kecenderungan Variabel}

Deskripsi selanjutnya adalah melakukan pengkategorian skor masing-masing variabel. Dari skor tersebut kemudian dibagi dalam 3 kategori. Pengkategorian dilaksanakan berdasarkan mean dan standar deviasi ideal. Adapun menurut Anas (2006: 176) ketiga kategori tersebut: 
Baik

$$
=\mathrm{M}+1 \mathrm{SD}<\mathrm{x}
$$

Cukup baik

$$
=\mathrm{M}-1 \mathrm{SD} \leq \mathrm{x} \leq \mathrm{M}+1 \mathrm{SD}
$$

Kurang baik

$$
=\mathrm{x}<\mathrm{M}-1 \mathrm{SD}
$$

$\mathrm{M}$

$=1 / 2($ skor tertinggi + skor terendah $)$

SD

$$
=1 / 6 \text { (skor tertinggi - skor terendah) }
$$

\section{4) Hasil Angket}

Deskripsi selanjutnya adalah menghitung hasil nilai masing-masing variabel. Dari nilai tersebut kemudian dibagi dalam 4 persentase: sangat setuju, setuju, tidak setuju dan sangat tidak setuju.

\section{Hasil Penelitian dan Pembahasan}

\section{Hasil Penelitian}

Perhitungan mean ideal dan standar deviasi ideal instrumen persepsi karyawan tentang peran auditor internal sebagai pengawas adalah $\mathrm{M}=1 / 2(32+8)=$ 20 dan $\mathrm{SD}=1 / 6(32-8)=4$

Dari perhitungan di atas dapat dikategorikan dalam 3 kelas seperti sebagai berikut:

Baik $=M+1 S D<x=24<x$

Cukup baik $=\mathrm{M}-1 \mathrm{SD} \leq \mathrm{x} \leq \mathrm{M}+1 \mathrm{SD}=16 \leq \mathrm{x}$ $\leq 24$

Kurang baik $=\mathrm{x}<\mathrm{M}-1 \mathrm{SD}=\mathrm{x}<16$

Tabel 7. Distribusi Kecenderungan Frekuensi

\begin{tabular}{|c|c|c|c|c|c|}
\hline \multirow[b]{2}{*}{ No } & \multirow[b]{2}{*}{ Interval } & \multicolumn{3}{|c|}{ Frekuensi } & \multirow[b]{2}{*}{ Kategori } \\
\hline & & $\begin{array}{l}\mathrm{Ab}- \\
\text { solut }\end{array}$ & $\begin{array}{l}\text { Rel } \\
\text { atif }\end{array}$ & $\begin{array}{c}\text { Kumu- } \\
\text { latif }\end{array}$ & \\
\hline 1 & $24<x$ & 22 & $\begin{array}{l}31, \\
9 \%\end{array}$ & $31,9 \%$ & Baik \\
\hline 2 & $\begin{array}{l}16 \leq x \leq \\
24\end{array}$ & 47 & $\begin{array}{l}68, \\
1 \%\end{array}$ & $100 \%$ & $\begin{array}{l}\text { Cukup } \\
\text { baik }\end{array}$ \\
\hline 3 & $x<16$ & 0 & $0 \%$ & $100 \%$ & $\begin{array}{l}\text { Kurang } \\
\text { baik }\end{array}$ \\
\hline
\end{tabular}
Variabel Persepsi Karyawan Tentang Peran Auditor Internal Sebagai Pengawas dalam Pencapaian Tujuan Perusahaan

Sumber: data primer yang diolah, 2012

Perhitungan mean ideal dan standar deviasi ideal instrumen persepsi karyawan tentang peran auditor internal sebagai konsultan adalah

$$
\mathrm{M}=1 / 2(32+8)=20 \text { dan } \mathrm{SD}=1 / 6(32-8)=4
$$

berikut:

Baik $=M+1 S D<x=24<x$

Cukup baik $=\mathrm{M}-1 \mathrm{SD} \leq \mathrm{x} \leq \mathrm{M}+1 \mathrm{SD}=16 \leq \mathrm{x}$ $\leq 24$

Kurang baik $=\mathrm{x}<\mathrm{M}-1 \mathrm{SD}=\mathrm{x}<16$

Tabel 8. Distribusi Kecenderungan Frekuensi Variabel Persepsi Karyawan Tentang Peran Auditor Internal Sebagai Konsultan dalam Pencapaian Tujuan Perusahaan

\begin{tabular}{|c|l|l|l|l|l|}
\hline \multirow{2}{*}{$\begin{array}{c}\mathrm{N} \\
\mathrm{O}\end{array}$} & \multirow{2}{*}{ Interval } & \multicolumn{3}{|c|}{ Frekuensi } & \multirow{2}{*}{ Kategori } \\
\cline { 3 - 5 } & $\begin{array}{l}\text { Ab- } \\
\text { solut }\end{array}$ & $\begin{array}{l}\text { Rela } \\
\text { tif }\end{array}$ & $\begin{array}{l}\text { Kumu- } \\
\text { latif }\end{array}$ & \\
\hline 1 & $24<\mathrm{x}$ & 5 & $7,2 \%$ & $7,2 \%$ & Baik \\
\hline 2 & $\begin{array}{l}16 \leq \mathrm{x} \leq \\
24\end{array}$ & 60 & $87 \%$ & $94,2 \%$ & Cukup baik \\
\hline 3 & $\mathrm{x}<16$ & 4 & $5,8 \%$ & $100 \%$ & Kurang baik \\
\hline
\end{tabular}

Sumber: data primer yang diolah, 2012

Perhitungan mean ideal dan standar deviasi ideal instrumen persepsi karyawan tentang peran auditor internal sebagai katalisator adalah $\mathrm{M}=1 / 2(32+8)$ $=20$ dan $\mathrm{SD}=1 / 6(32-8)=4$

Dari perhitungan di atas dapat dikategorikan dalam 3 kelas seperti sebagai berikut:

Baik $=M+1 S D<x=24<x$

Cukup baik $=\mathrm{M}-1 \mathrm{SD} \leq \mathrm{x} \leq \mathrm{M}+1 \mathrm{SD}=16 \leq \mathrm{x}$ $\leq 24$

Kurang baik $=\mathrm{x}<\mathrm{M}-1 \mathrm{SD}=\mathrm{x}<16$

Tabel 9. Distribusi Kecenderungan Frekuensi Variabel Persepsi Karyawan Tentang Peran Auditor Internal Sebagai Katalisator dalam Pencapaian Tujuan Perusahaan

\begin{tabular}{|l|l|l|l|l|l|}
\hline \multirow{2}{*}{$\begin{array}{c}\mathrm{N} \\
\mathrm{O}\end{array}$} & \multirow{2}{*}{ Interval } & \multicolumn{3}{|c|}{ Frekuensi } & \multirow{2}{*}{ Kategori } \\
\cline { 3 - 5 } & $\begin{array}{l}\text { Ab- } \\
\text { solut }\end{array}$ & $\begin{array}{l}\text { Rela } \\
\text { tif }\end{array}$ & $\begin{array}{l}\text { Kumu- } \\
\text { latif }\end{array}$ & \\
\hline 1 & $24<\mathrm{x}$ & 0 & $0 \%$ & $0 \%$ & Baik \\
\hline 2 & $\begin{array}{l}16 \leq \mathrm{x} \leq \\
24\end{array}$ & 56 & $\begin{array}{l}81,2 \\
\%\end{array}$ & $81,2 \%$ & Cukup baik \\
\hline 3 & $\mathrm{x}<16$ & 13 & $\begin{array}{l}18,8 \\
\%\end{array}$ & $100 \%$ & Kurang baik \\
\hline
\end{tabular}

Sumber: data primer yang diolah, 2012 


\section{Jurnal Nominal / Volume I Nomor I / Tahun 2012}

Tabel 10. Total Skor dari Persepsi Karyawan Tentang Peran Auditor Internal baik Sebagai Pengawas, Konsultan, dan Katalisator dalam Pencapaian Tujuan Perusahaan

\begin{tabular}{|c|c|c|c|c|c|c|c|}
\hline Tanggapan & $\begin{array}{c}\text { Bobot } \\
(1)\end{array}$ & $\begin{array}{c}\text { Pengawas } \\
(2)\end{array}$ & $\begin{array}{c}\text { Nilai } \\
(3)\end{array}$ & $\begin{array}{c}\text { Konsultan } \\
(4)\end{array}$ & $\begin{array}{c}\text { Nilai } \\
(5)\end{array}$ & $\begin{array}{c}\text { Natalisator } \\
(6)\end{array}$ & (7) \\
\hline SS & 4 & 102 & 408 & 18 & 72 & 10 & 40 \\
\hline S & 3 & 321 & 963 & 288 & 864 & 273 & 819 \\
\hline TS & 2 & 125 & 250 & 213 & 426 & 224 & 448 \\
\hline STS & 1 & 4 & 4 & 33 & 33 & 45 & 45 \\
\hline Total & & 552 & 1.625 & 552 & 1.395 & 552 & 1.352 \\
\hline
\end{tabular}

Sumber: data primer yang diolah, 2012

Keterangan tabel:

SS

: Sangat Setuju

$\mathrm{S}$

: Setuju

TS

$$
\text { : Tidak Setuju }
$$

STS

$$
\text { : Sangat Tidak Setuju }
$$

Kolom Nilai (3): Kolom Bobot (1) x Kolom

Pengawas (2)

Kolom Nilai (5): Kolom Bobot (1) x Kolom Konsultan (4)

Kolom Nilai (7): Kolom Bobot (1) x Kolom Katalisator (6)

Tabel 11. Hasil Pemberian Peringkat pada Persepsi Karyawan Tentang Peran Auditor Internal dalam Pencapaian Tujuan Perusahaan

\begin{tabular}{|l|l|l|l|}
\hline $\begin{array}{c}\text { Peran Auditor } \\
\text { Internal }\end{array}$ & Total Nilai & Persentase & $\begin{array}{c}\text { Pering- } \\
\text { kat }\end{array}$ \\
\hline Pengawas & 1.625 & $37,17 \%$ & $\mathrm{I}$ \\
\hline Konsultan & 1.395 & $31,91 \%$ & $\mathrm{II}$ \\
\hline Katalisator & 1.352 & $30,92 \%$ & $\mathrm{III}$ \\
\hline Total & 4.372 & $100 \%$ & \\
\hline
\end{tabular}

Sumber: data yang diolah, 2012

Berdasarkan tabel di atas, menunjukkan bahwa persepsi karyawan tentang peran auditor internal sebagai pengawas dalam pencapaian tujuan perusahaan mempunyai total nilai tertinggi yaitu 1.625 $(37,17 \%)$ dari total keseluruhan. Kemudian diperingkat II adalah persepsi karyawan tentang peran auditor internal sebagai konsultan dalam pencapaian tujuan perusahaan mempunyai total nilai sebesar $1.395(31,91 \%)$ dari total keseluruhan. Peringkat III adalah persepsi karyawan tentang peran auditor internal sebagai katalisator dalam pencapaian tujuan perusahaan yang memiliki total nilai sebesar $1.352(30,92 \%)$ dari total keseluruhan.

\section{Pembahasan}

Fungsi auditor internal yang semakin berkembang, membawa pergeseran paradigma dari para pemakainya. Pada paradigma lama tentang peran auditor internal yaitu berfokus pada ditemukannya penyimpangan yang perlu dikoreksi serta lebih banyak dilakukan pemeriksaan pada tingkat kepatuhan para pelaksana pada ketentuan yang telah ditetapkan. Peran auditor internal seperti ini serupa dengan peran polisi atau pengawas yang melakukan pemeriksaan. Peran auditor internal sebagai pengawas sering dianggap sebagai pihak pencari kesalahan yang diutus oleh pimpinan perusahaan. Seiring berjalannya waktu, paradigma lama tentang peran aditor internal mengalami pergeseran ke paradigma baru yang awalnya auditor internal berperan sebagai pengawas, kini beralih menjadi auditor internal yang berperan sebagai konsultan dan diprediksikan di masa mendatang auditor internal berperan sebagai katalisator. Dengan peran sebagai konsultan, auditor internal lebih berfungsi sebagai mitra bagi klien yang merupakan bentuk pelayanan pada perusahaan dalam rangka membantu pencapaian tujuan. Sedangkan di masa mendatang dimungkinkan auditor internal peran sebagai katalisator yang akan ikut andil dalam menentukan tujuan perusahaan.

Hasil dari persepsi karyawan tentang peran auditor internal dalam pencapaian tujuan perusahaan pada tabel. 21, dapat diketahui bahwa 69 responden karyawan Hotel Inna Garuda Yogyakarta berpersepsi tentang peran auditor internal sebagai pengawas dengan total 552 persepsi dan total nilai 1.625 dari 8 item pernyataan yaitu mulai dari pernyataan P1 sampai dengan pernyataan P8. Responden yang menyatakan sangat setuju adalah 102 responden dengan jumlah nilai 408, 321 responden menyatakan setuju dengan jumlah nilai 963. Sedangkan 
125 responden menyatakan tidak setuju dengan jumlah nilai 250 , dan 4 responden menyatakan sangat tidak setuju dengan jumlah nilai 4 .

Persepsi karyawan Hotel Inna Garuda Yogyakarta yang menyatakan setuju tentang peran auditor internal sebagai pengawas, mencerminkan bahwa peran auditor internal di Hotel Inna Garuda Yogyakarta berfokus pada pendekatan kepatuhan dan menjalankan tugas seperti layaknya polisi dengan menjaga keamanan, kelancaran, kesesuaian aktivitas dengan peraturan yang berlaku. Di mana peran auditor internal sebagai pengawas dianggap sebagai pihak yang diutus pimpinan untuk mencari kesalahan karyawan yang sebenarnya dapat berimbas pada kenyamanan karyawan dalam melaksanakan pekerjaannya. Didukung dengan teori paradigma lama dalam Tampubolon (2005, 1-2) yang menyatakan bahwa auditor internal sebagai pengawas lebih berperan sebagai mata telinga manajemen, karena manajemen membutuhkan kepastian bahwa kebijakan yang ditetapkan akan dilaksanakan oleh karyawan. Terkait dengan saran dan rekomendasi yang diberikan auditor internal sebagai pengawas lebih bersifat jangka pendek dalam membantu pencapaian tujuan perusahaan.

Seiring berjalannya waktu peran auditor internal meningkat menjadi konsultan dan mulai diterapkan di perusahaan-perusahaan maju yang di mana pada peran ini auditor turut serta memastikan bahwa kontrol internal telah berfungsi dengan baik. Hasil dari persepsi karyawan tentang peran auditor internal dalam pencapaian tujuan perusahaan pada tabel. 21, dapat diketahui bahwa 69 responden karyawan Hotel Inna Garuda Yogyakarta berpersepsi tentang peran auditor internal sebagai konsultan dengan total 552 persepsi dan total nilai 1.395 dari 8 item pernyataan yaitu mulai dari pernyataan K1 sampai dengan pernyataan K8. Responden yang menyatakan sangat setuju adalah 18 responden dengan jumlah nilai 72, 288 responden menyatakan setuju dengan jumlah nilai 864. Sedangkan 213 responden menyatakan tidak setuju dengan jumlah nilai 426, dan 33 responden menyatakan sangat tidak setuju dengan jumlah nilai 33.

Persepsi karyawan Hotel Inna Garuda Yogyakarta yang menyatakan setuju tentang peran auditor internal sebagai konsultan dalam pencapaian tujuan perusahaan mencerminkan bahwa auditor internal Hotel Inna Garuda Yogyakarta telah menjalankan peran sebagai konsultan dengan membantu perusahaan dalam menilai dan mengevaluasi kegiatan perusahaan dengan tujuan agar perusahaan menghasilkan pelayanan dan mutu yang baik dengan memanfaatkan sumber daya yang ada.
Selain itu mencerminkan pula bahwa auditor internal Hotel Inna Garuda Yogyakarta telah menjalankan perannya sesuai dengan redefinisi IAI pada tahun 1999 yang menjelaskan bahwa audit internal merupakan suatu aktivitas independen dalam menetapkan tujuan dan merancang aktivitas konsultasi yang bernilai tambah bagi klien. Didukung dengan teori paradigma baru dalam Tampubolon (2005, 1-2) yang menyatakan peran auditor internal sebagai konsultan wajib melayani klien dengan baik dan mendukung kepentingan klien dengan tetap mempertahankan loyalitas pada perusahaan maka auditor internal sebagai konsultan tidak hanya melaksanakan fungsi sebagai pemeriksa, tetapi auditor internal juga berfungsi sebagai mitra bagi klien dalam hal ini Hotel Inna Garuda Yogyakarta. Dengan peran auditor internal sebagai konsultan dapat membantu perusahaan dalam pencapaian tujuan yang tercermin dalam rekomendasi dan saran yang diberikan lebih bersifat jangka menengah.

Di masa yang akan datang, auditor internal dimungkinkan berperan sebagai katalisator yang akan ikut menentukan tujuan perusahaan. Hasil dari persepsi karyawan tentang peran auditor internal dalam pencapaian tujuan perusahaan pada tabel. 21, dapat diketahui bahwa 69 responden karyawan Hotel Inna Garuda Yogyakarta berpersepsi tentang peran auditor internal sebagai katalisator dengan total 552 persepsi dan total nilai 1.352 dari 8 item pernyataan yaitu mulai dari pernyataan $\mathrm{Kt} 1$ sampai dengan pernyataan Kt8. Responden yang menyatakan sangat setuju adalah 10 responden dengan jumlah nilai 40, 273 responden menyatakan setuju dengan jumlah nilai 819. Sedangkan 224 responden menyatakan tidak setuju dengan jumlah nilai 448 , dan 45 responden menyatakan sangat tidak setuju dengan jumlah nilai 45 .

Persepsi karyawan Hotel Inna Garuda Yogyakarta yang menyatakan setuju terhadap peran auditor internal sebagai katalisator mencerminkan bahwa auditor internal Hotel Inna Garuda Yogyakarta dalam kegiatan auditnya menerapkan perannya sebagai katalisator yang ikut menentukan arah dan tujuan Hotel Inna Garuda Yogyakarta serta dapat membimbing manajemen dalam mengenali risikorisiko yang mengancam pencapaian tujuan perusahaan. Sesuai dengan teori tentang peran auditor internal sebagai katalisator dalam Harry Andrian Simbolon (2010: 1) yang mengatakan peran auditor internal sebagai katalisator bertindak sebagai fasilitator dan agent of change, di mana rekomendasi dan saran yang diberikan dalam membantu pencapaian tujuan perusahaan lebih bersifat jangka panjang. 
Jumlah nilai persepsi karyawan tentang peran auditor internal sebagai pengawas dalam pencapaian tujuan perusahaan sesuai dengan tabel 22 sebesar $1.625(37,17 \%)$ dan menduduki peringkat I. Pada tabel 13, dapat diketahui bahwa distribusi kecenderungan frekuensi variabel persepsi karyawan tentang peran auditor internal sebagai pengawas dalam pencapaian tujuan perusahaan dengan frekuensi absolut sebesar 47 dan frekuensi relatif $68,1 \%$ yang dikategorikan cukup baik.

Dengan melihat tabel 22 yaitu hasil pemberian peringkat pada persepsi karyawan tentang peran auditor internal dalam pencapaian tujuan perusahaan, dapat diketahui bahwa jumlah nilai peran auditor internal sebagai konsultan sebesar 1.395 (31,91\%) dan menduduki peringkat II. Pada tabel 13, dapat diketahui bahwa distribusi kecenderungan frekuensi variabel persepsi karyawan tentang peran auditor internal sebagai konsultan dalam pencapaian tujuan perusahaan dengan frekuensi absolut sebesar 60 dan frekuensi relatif sebesar $87 \%$ yang dikategorikan cukup baik.

Jumlah nilai persepsi karyawan tentang peran auditor internal sebagai katalisator dalam pencapaian tujuan perusahaan sesuai dengan tabel 22 sebesar $1.352(30,92 \%)$ dan menduduki peringkat III. Pada tabel 13, dapat diketahui bahwa distribusi kecenderungan frekuensi variabel persepsi karyawan tentang peran auditor internal sebagai katalisator dalam pencapaian tujuan perusahaan dengan frekuensi absolut sebesar 56 dan frekuensi relatif sebesar $81,2 \%$ yang dikategorikan cukup baik.

Dari hasil perhitungan distribusi kecenderungan frekuensi variabel persepsi karyawan tentang peran auditor internal dapat diketahui bahwa persebaran data dari masing-masing variabel baik peran auditor internal sebagai pengawas, konsultan, dan katalisator dapat dikategorikan cukup baik. Perhitungannya tersebut dilakukan dengan menggunakan mean ideal dan standar deviasi ideal. Pengkategorian tersebut menunjukan tingkat pemahaman karyawan yang cukup baik dari ketiga peran yang dijalankan auditor internal.

Persepsi karyawan tentang peran auditor internal sebagai pengawas dalam membantu pencapaian tujuan perusahaan lebih cenderung pada tindakan auditor internal yang melakukan inspeksi dan pengawasan terhadap kepatuhan karyawan pada peraturan dan kebijakan yang ditetapkan, yang kemudian diikuti tindakan auditor internal sebagai pengawas lainnya seperti mencocokan data (catatan) transaksi dengan bukti-bukti, melakukan penghitungan ulang terhadap catatan angka-angka dan transaksi-transaksi yang terdapat dalam laporan keuangan, memeriksa fisik kas yang diterima dengan bukti penerimaan, dan melakukan penghitungan fisik terhadap uang kas. Kecenderungan persepsi karyawan pada tindakan itu menunjukan bahwa peran auditor internal sebagai pengawas dalam membantu pencapaian tujuan perusahaan lebih pada pihak yang melakukan audit kepatuhan dengan melakukan pengawasan apakah karyawan mematuhi peraturan dan kebijakan yang telah ditetapkan dalam perusahaan. Tindakan tersebut dilakukan karena di sini auditor internal membantu manajemen untuk mendapatkan kepastian bahwa kebijakan yang ditetapkan akan dilaksanakan oleh karyawan.

Persepsi karyawan tentang peran auditor internal sebagai konsultan dalam membantu pencapaian tujuan perusahaan lebih cenderung pada tindakan auditor internal yang memberi rekomendasi tindakan korektif kepada karyawan, yang kemudian diikuti tindakan auditor internal sebagai konsultan lainnya seperti memberi jasa konsultasi dan memberikan kontribusi bagi pencapaian tujuan dan peningkatan kemakmuran perusahaan, mengevaluasi kesesuaian aktivitas dengan hukum, regulasi, dan standar yang berlaku, menganalisis kecukupan dan efektivitas pengendalian internal yang ada, mengevaluasi perbaikan aktivitas yang berkesinambungan dan pengadopsian praktek yang sehat dan efektif, dan mengevaluasi program dan kegiatan operasi apakah telah berfungsi sebagaimana mestinya dan memberi hasil yang sesuai. Kecenderungan persepsi karyawan pada tindakan itu menunjukan bahwa peran auditor internal sebagai konsultan dalam membantu pencapaian tujuan perusahaan lebih pada pihak yang memberikan tindakan korektif yang tercermin dari rekomendasi yang diberikan.

Persepsi karyawan tentang peran auditor internal sebagai katalisator dalam membantu pencapaian tujuan perusahaan merupakan peran yang lebih cenderung pada tindakan auditor internal yang mengarahkan pelaksanaan kualitas manajemen agar sesuai dengan yang direncanakan, yang kemudian diikuti tindakan auditor internal sebagai katalisator lainnya seperti memberi sumbangan pada proses manajemen risiko, tata kelola (governance) dan kontrol, menganalisis masukan dari pihak yang diaudit dan secara positif memberikan reaksi terhadap masukan tersebut, melakukan analisis risiko atas aktivitas tertentu yang ada dalam perusahaan, mengidentifikasi risiko karena adanya perubahan yang terjadi dalam perusahaan, dan melakukan analisis risiko terhadap pesaing atau kompetitor yang potensial. Kecender- 
ungan persepsi karyawan pada tindakan itu menunjukan bahwa peran auditor internal sebagai katalisator dalam membantu pencapaian tujuan perusahaan lebih pada pihak yang melakukan pengarahan agar apa yang direncanakan dapat tercapai.

Terkait dengan pemberian peringkat, berdasarkan hasil analisis data dapat diketahui bahwa persepsi karyawan Hotel Inna Garuda Yogyakarta tentang peran auditor internal sebagai pengawas dalam pencapaian tujuan perusahaan menduduki peringkat I, diikuti dengan peran auditor internal sebagai konsultan yang menduduki peringkat II, dan sebagai katalisator menduduki peringkat III. Hasil ini mencerminkan bahwa persepsi karyawan tentang peran auditor internal Hotel Inna Garuda Yogyakarta dalam membantu pencapaian tujuan perusahaan lebih mengarah pada peran sebagai pengawas yaitu dengan perolehan skor tertinggi dan menduduki peringkat I. Peran yang dijalankan auditor internal perusahaan masing menganut paradigma lama yang sebenarnya saran dan rekomendasi yang diberikan peran ini hanya bersifat jangka pendek dalam membantu perusahaan untuk mencapai tujuan. Karyawan berpersepsi bahwa peran yang dijalankan auditor internal adalah sebagai pengawas karena tindakan selayaknya polisi yang dijalani auditor internal, di mana tindakan itu membuat karyawan merasa tidak nyaman dan membuat karyawan kurang menyukai kehadirannya.

Peran auditor internal sebagai konsultan yang menduduki peringkat II menunjukan bahwa menurut persepsi karyawan peran ini tidak begitu dominan dalam pelaksanaannya dibandingkan dengan peran sebagai pengawas yang dijalankan auditor internal Hotel Inna Garuda Yogyakarta. Persepsi ini timbul karena auditor internal perusahaan lebih menjalankan perannya sebagai pihak yang melakukan inspeksi dan pengawasan terhadap kepatuhan karyawan pada peraturan dan kebijakan yang telah ditetapkan dibandingkan dengan perannya sebagai pihak pemberi saran dan rekomendasi yang membantu karyawan dalam memecahkan masalah terkait dengan kegiatan operasional perusahaan. Sebenarnya sesuai dengan redefinisi IAI pada tahun 1999 tentang peran audit internal menyatakan akan lebih efektif dan memberi nilai tambah bagi perusahaan jika auditor internal suatu perusahaan merancang aktivitas konsultasi, yang di mana aktivitas ini terkait dengan peran auditor internal sebagai konsultan.

Peran auditor internal sebagai katalisator yang menduduki peringkat terakhir ini menunjukan bahwa menurut persepsi karyawan, peran ini merupa- kan peran yang paling sedikit dijalankan auditor internal Hotel Inna Garuda Yogyakarta dalam membantu pencapaian tujuan perusahaan. Persepsi ini timbul selain karena auditor internal perusahaan lebih menjalankan perannya sebagai pihak yang melakukan inspeksi dan pengawasan terhadap kepatuhan, tetapi juga karena untuk menerapkan peran ini secara penuh membutuhkan waktu dan proses yang cukup panjang, dengan peran auditor internal sebagai katalisator dimungkinkan akan ikut andil dalam menentukan tujuan yang hendak dicapai Hotel Inna Garuda Yogyakarta.

\section{Pentup}

\section{1) Kesimpulan}

a. Persepsi karyawan tentang peran auditor internal sebagai pengawas dalam pencapaian tujuan perusahaan berdasarkan hasil perhitungan distribusi kecenderungan frekuensi variabel dapat diketahui bahwa persebaran data dari peran ini dikategorikan cukup baik, yang di mana untuk frekuensi absolut sebesar 47 dan frekuensi relatif $68,1 \%$. Berdasarkan tabel. 23 dapat diketahui auditor internal sebagai pengawas menduduki peringkat I dengan total skor sebesar 1.625 $(37,17 \%)$. Peran yang dijalankan auditor internal perusahaan masing menganut paradigma lama yang sebenarnya saran dan rekomendasi yang diberikan peran ini hanya bersifat jangka pendek dalam membantu perusahaan untuk mencapai tujuan. Tindakan selayaknya polisi yang dijalani auditor internal sebagai pengawas dapat membuat karyawan merasa tidak nyaman dan membuat karyawan kurang menyukai kehadirannya sehingga kinerja yang mereka kurang maksimal. Selain itu tindakkan selayaknya polisi membuat karyawan menganggap auditor internal adalah lawan mereka. Dengan peran auditor internal sebagai pengawas juga dianggap karyawan kurang memberikan kontribusi yang maksimal dalam membantu pencapaian tujuan perusahaan.

b. Persepsi karyawan tentang peran auditor internal sebagai konsultan dalam pencapaian tujuan perusahaan berdasarkan hasil perhitungan distribusi kecenderungan frekuensi variabel dapat diketahui bahwa persebaran data dari peran ini dikategorikan cukup baik, yang di mana untuk frekuensi absolut sebesar 60 dan frekuensi relatif 87\%. Berdasarkan tabel. 23 dapat diketahui auditor internal sebagai konsultan menduduki peringkat II dengan total skor sebesar 1.395 $(31,91 \%)$. Peran sebagai konsultan yang dijalankan auditor internal Hotel Inna Garuda Yogya- 
karta belum begitu maksimal sehingga hanya menduduki peringkat II. Pada kenyataanya karyawan Hotel Inna Garuda Yogyakarta membutuhkan auditor internal yang tidak hanya berfokus pada penemuan kecurangan yang terjadi tetapi juga berperan sebagai konsultan internal yang memberikan masukan dan pemikiran dalam membantu pencapaian tujuan perusahaan serta dapat menunjang efektivitas pengendalian atas kegiatan-kegiatan yang berjalan di Hotel Inna Garuda Yogyakarta. Didukung dengan redefinisi yang dikemukakan IAI pada tahun 1999 tentang peran audit internal menyatakan akan bahwa lebih efektif dalam pencapaian tujuan perusahaan dan memberi nilai tambah bagi perusahaan jika auditor internal suatu perusahaan merancang aktivitas konsultasi, yang di mana aktivitas ini terkait dengan peran auditor internal sebagai konsultan.

c. Persepsi karyawan tentang peran auditor internal sebagai katalisator dalam pencapaian tujuan perusahaan berdasarkan hasil perhitungan distribusi kecenderungan frekuensi variabel dapat diketahui bahwa persebaran data dari peran ini dikategorikan cukup baik, yang di mana untuk frekuensi absolut sebesar 56 dan frekuensi relatif 81,2\%. Berdasarkan tabel. 23 dapat diketahui auditor internal sebagai katalisator menduduki peringkat III dengan total skor sebesar 1.352 (30,92\%). Peran ini merupakan peran yang paling sedikit diperankan oleh auditor internal Hotel Inna Garuda Yogyakarta. Dalam menerapkan peran ini secara penuh membutuhkan waktu dan proses yang cukup panjang, peran auditor internal sebagai katalisator dimungkinkan akan ikut serta dalam menentukan tujuan Hotel Inna Garuda Yogyakarta.

\section{2) Saran}

Berdasarkan hasil penelitian, terdapat saran-saran yang dapat dijadikan masukan guna meningkatkan peran dan tanggung jawab auditor internal agar dapat membatu dalam pencapaian tujuan Hotel Inna Garuda Yogyakarta:

1. Agar Hotel Inna Garuda Yogyakarta dapat terus berkembang dan tujuan perusahaan yang telah ditetapkan dapat tercapai, diperlukan suatu kerjasama di setiap bagian atau departemen, terutama Auditor Internal yang dituntut untuk terus berinteraksi menjalin kerjasama dengan staf perusahaan agar tercipta suatu kerjasama yang baik seperti diungkapkan dalam tujuan perusahaan yaitu meningkatkan suasana kerja yang kondusif serta kooperatif untuk mewujudkan kepuasan kerja dan kesejahteraan karyawan.

2. Auditor Internal Hotel Inna Garuda Yogyakarta diharapkan dapat meningkatkan perannya sebagai konsultan karena menurut persepsi karyawan dengan perannya yang sekarang ini sudah dijalankan kurang memberikan kontribusi yang maksimal dalam pencapaian tujuan perusahaan dan membuat karyawan kurang menyukai dan tidak nyaman dengan peran yang dijalankan sekarang. Dengan meningkatkan peran auditor internal sebagai konsultan, akan lebih efektif dalam membantu karyawan dan memberi nilai tambah bagi perusahaan untuk mencapai tujuan perusahaan.

3. Membimbing manajemen untuk mengenali risiko yang dapat menghambat pencapaian tujuan perusahaan sebaiknya diterapkan oleh Auditor Internal Hotel Inna Garuda Yogyakarta dan membatu dalam menentukan tujuan perusahaan, yang di mana peran ini terkait dengan peran auditor internal sebagai katalisator. Akan tetapi, yang perlu diingat dalam menjalankan peran ini, auditor hanya sebagai fasilitaor atau agen of change, bukan sebagai pihak yang memberikan keputusan tentang langkah apa yang harus diambil karena yang berhak memutuskan adalah manajemen dalam perusahaan.

\section{3) Keterbatasan}

Keterbatasan yang terdapat dalam penelitian ini adalah sebagai berikut:

1. Keterbatasan kemampuan responden untuk memahami isi pernyataan serta kejujuran untuk menjawab kuesioner yang diberikan, karena kemungkinan kesalahan dalam menjawab dapat terjadi.

2. Penyebaran kuesioner kepada responden yang tidak dilakukan oleh peneliti sendiri menyebabkan peneliti tidak mengetahui apakah kuesioner tersebut disebarkan sebagaimana mestinya.

\section{E. Daftar Pustaka}

Anas Sudijono. (2006). Pengantar Statistik Pendidikan. Jakarta: PT Raja Grafindo Persada.

Anita Romauli. (2011). Persepsi Mahasiswa Akuntansi Tentang Standar Akuntansi Keuangan Entitas Tanpa Akuntabilitas Publik (Sak-Etap) Bagi Usaha Mikro Kecil Dan Menengah. Skripsi. Universitas Negeri Yogyakarta. 
Emanuela Deasy Novieyanty. (2006). Persepsi Karyawan Terhadap Auditor Internal pada Pelayanan Kesehatan St. Carolus Jakarta. Skripsi. Yogyakarta: FE-USD.

Kreitner, Robert dan Angelo Kinicki. (2003). Perilaku organisasi (Organizational Behaviour). Jakarta: Salemba Empat.

Listiatik. (2007). Persepsi Keryawan Tentang Auditor Internal pada Rumah Sakit Panti Rapih. Skripsi. Yogyakarta: FE-USD.

Nur Indriantoro dan Bambang Supomo. (1999). Metodologi Penelitian Bisnis untuk Akuntansi dan Manajemen. Yogyakarta: BPFE.

Sawyer, Lawrence B. (2000). Internal Auditing. Edisi 5. Jakarta: Salemba Empat.

Simbolon, Harry Andrian. (2010).Paradigma Baru Audit Internal. Diambil dari: http:// akuntansibisnis.wordpress.com/feed/, pada tanggal 3 Februari 2012.

Singgih Santoso. 2003. Statistik Diskriptif Konsep dan Aplikasi dengan Microsoft Excel dan SPSS. Yogyakarta: Andi Offset

Sugiyono. (2008). Statistika untuk Penelitian. Bandung: Alfabeta.
Suharnan. (2005). Psikologi Kognitif. Surabaya: Srikandi.

Suharsimi Arikunto. (2005). Manajemen Penelitian. Edisi Revisi. Jakarta: PT. Rineka Cipta.

Sukrisno Agoes. (2004). Auditing (Pemeriksaan Auntan). Jilid 2. Edisi ketiga. Jakarta: FE-UI.

Supriyanto Ilyas dan Maulana Prima Aryawan. (2007). Pergeseran Paradigma tentang Fungsi Audit internal Serta Kaitannya dengan Aspek Teknologi Informasi dalam Organisasi Perguruan Tinggi. Jurnal Universitas Widyatama. Hal. 4-5.

Suroso. (2009). Kedudukan dan Fungsi Audit Internal dalam Perusahaan. Jurnal Ilmiah Abadi Ilmu. Vol. 2 No.2: Hal. 230.

Tampubolon, Robert. (2005). Risk and SystemBased Internal Audit. Jakarta: Elex Media Komputindo.

Walgito. (2005). Pengantar Psikologi Umum. Yogyakarta: Andi Offset.

Wibisono. (2006). Pengertian Visi dan Misi Perusahaan. Diambil dari: http://jurnalsdm.blogspot.com/2009/10/definisi-visi-misi-danstrategi-dan.html, pada tanggal 20 Februari 2012. 